

\section{THE BRYOLOGIST}

A JOURNAL OF BRYOLOGY AND LiCHENOLOGY

VOLUME 108

WINTER 2005

NUMBER 4

The Bryologist $108(4)$, pp. $481-486$ Copyright $(02005$ by the American Bryological and Lichenological Society, Inc.

\section{Gomphillus caribaeus Belongs in the New Genus Bryogomphus (Lecanorales: Pilocarpaceae)}

ROBERT LÜCKING

Department of Botany, The Field Museum, 1400 South Lake Shore Drive, Chicago, IL 60605-2496, U.S.A. e-mail: rlucking@fieldmuseum.org

WILLIAM R. BUCK

Institute of Systematic Botany, New York Botanical Garden, Bronx, NY 10458-5126, U.S.A. e-mail: bbuck@nybg.org

EMMANUËl SÉRUSIAUX

Plant Taxonomy \& Conservation Biology Unit, University of Liège, Sart Tilman B22, B-4000 Liège, Belgium; e-mail: e.serusiaux@ulg.ac.be

Lidia I. FERRARO

Instituto de Botanica del Nordeste (IBONE), Sargento Cabral 2131, 3400 Corrientes, Argentina; e-mail: Iferraro@ agr.unne.edu.ar

Abstract. A revision of the lichen genus Gomphillus Nyl. in the Americas reveals that $\mathrm{G}$. caribaeus W. R. Buck does not belong in that genus, but is a member of the Pilocarpaceae in the Lecanorales. Because of its distinctive features, the species cannot be accommodated in any of the known genera of that family, and the new genus Bryogomphus Lücking, W. R. Buck, Sérus. \& L. I. Ferraro is established for it. Bryogomphus is characterized by turbinate, vertically elongate, obconical apothecia with a disc-shaped top, anastomosing paraphyses forming a reticulum around individual asci, amyloid asci of the Sporopodium-type, and filiform, multiseptate ascospores. Most similar within the Pilocarpaceae is Bapalmuia marginalis, but that species differs in having unbranched, strongly coherent paraphyses and Byssoloma-type asci with a darker tubular structure in the tholus. Calopadia turbinata (Tuck.) Sérus. \& Lücking comb. nov. is also related but has a paraplectenchymatous excipulum, largely unbranched paraphyses, and oblong-ellipsoid, muriform ascospores. Bryogomphus shows a remarkable convergence with Gomphillus in the Gomphillaceae (Ostropales), being extremely similar even in many details, except for the amyloid asci, slightly thicker and irregularly bent paraphyses, externally thinly byssoid excipulum with labyrinthical structure, and disc-shaped top of the apothecia.

Keywords. Bapalmuia, Bryogomphus, Calopadia, Gomphillaceae, Gomphillus, Lopadium, muscicolous, Ostropales, Pilocarpaceae, Sporopodium, Tapellaria.

Initiated by the discovery of the new species Gomphillus pedersenii in Argentina, the first and last author (Ferraro \& Lücking 2005; this issue) compiled a synopsis of the genus for the Americas. While extracting diagnostic characters and prepar- ing a key to the supposedly five known species (Buck 1998; Esslinger 1975; Kalb \& Vězda 1988), some elements in the original description of Gomphillus caribaeus $\mathrm{W}$. R. Buck made it necessary to restudy the material cited in the protologue. Char- 

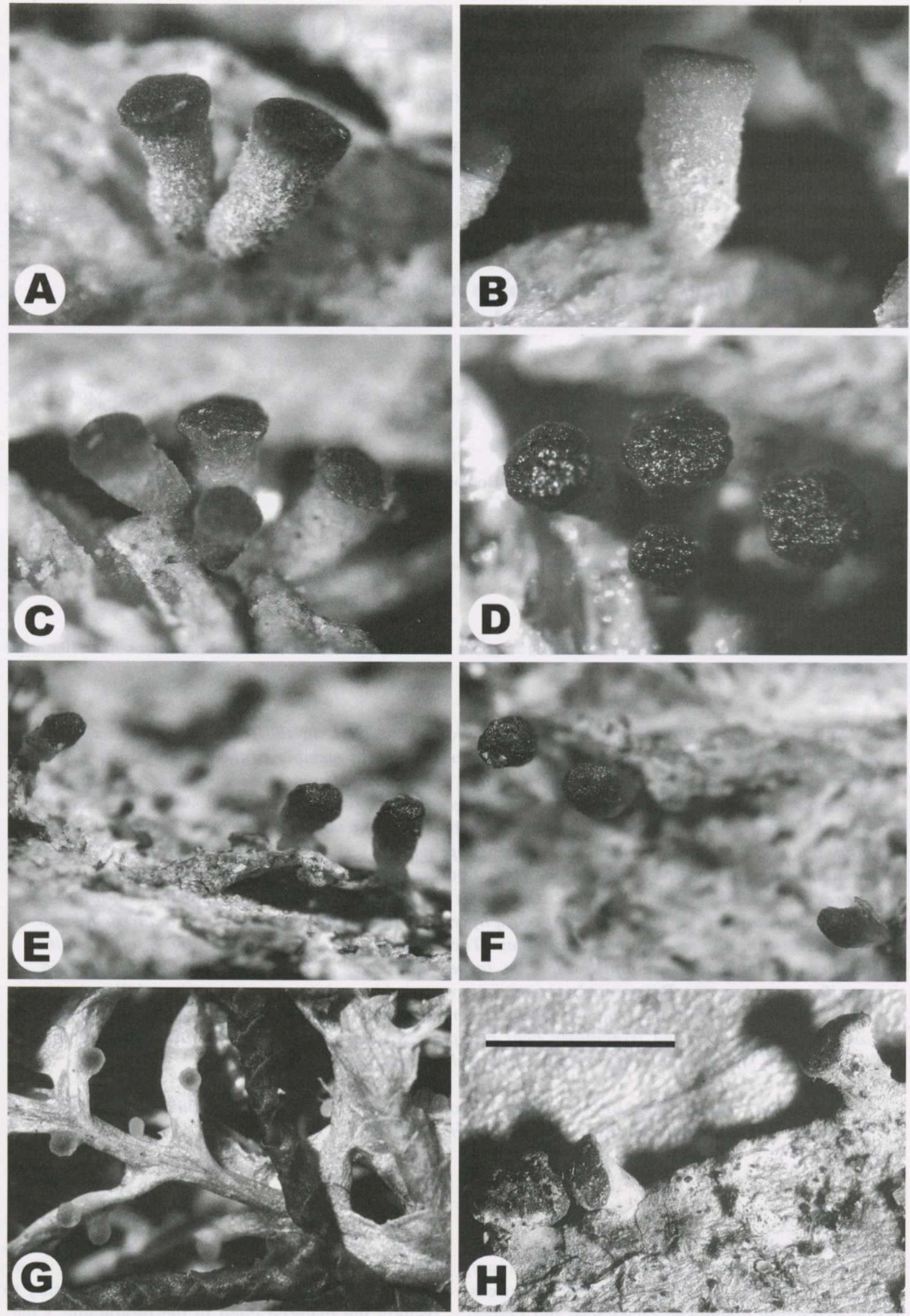
acters such as ". . . thallo minore minute granuloso ... excipulo ... tomentuloso crystall(i)fero . . ." (Buck 1998: 72) do not fit Gomphillus or the Gomphillaceae in general but rather point to certain members of the Pilocarpaceae. Representatives of that family frequently have a farinose-granulose thallus and a partly byssoid excipulum, and the genus Bapalmuia matches Gomphillus in having filiform, transversely multiseptate ascospores (Kalb et al. 2000; Sérusiaux 1993). There is even a species, B. marginalis (Vain.) Sérus. (FIG. 1H), with turbinate, vertically elongate apothecia like those of Gomphillus. That species and its similarities with Gomphillus calycioides (Del. ex Duby) Nyl. were already discussed by Santesson (1952; as Bacidia marginalis), and he concluded that ". . . in spite of these great similarities, Gomphillus calycioides and Bacidia marginalis are not close relatives ..." (Santesson 1952: 447-448). We therefore suspected that Gomphillus caribaeus could belong in the genus Bapalmuia and might even be identical with $B$. marginalis.

Surprisingly, when studying the type material and other specimens available, we found that, while Gomphillus caribaeus is indeed similar to Bapalmuia marginalis, it differs in important hamathecium and ascus characters and thus cannot be accommodated in the genus Bapalmuia. Instead, the new genus Bryogomphus, which combines features of Gomphillus, Bapalmuia, Sporopodium, and Tapellaria, is established to house this enigmatic taxon.

Bryogomphus Lücking, W. R. Buck, Sérus. \& L.

I. Ferraro, gen. nov. Figs. 1A-D, 2

Genus novum ascomycetum lichenisati ad familiae Pilocarpacearum in ordine Lecanoralibus pertinens. Sicut Gomphillus calycioides vel Bapalmuia marginalis, cum apotheciis turbinatis et ascosporis filiformibus transversaliter multiseptatis, sed Gomphillo ascis I+ caeruleis et $\mathrm{Ba}$ palmuia ascis ad typo Sporopodio pertinentibus et paraphysis ramoso-conexis $\mathrm{I}$ - differt.

Thallus smooth to farinose, ecorticate. Photobiont chlorococcoid. Apothecia turbinate, vertically elongate, obconical, with pale flanks and apically with a slightly expanded, flat to slightly convex, dark disc. Excipulum prosoplectenchymatous, with rather thick-walled cells in labyrinthical arrangement, yellowish brown, laterally with short, free hyphae (Bapalmuia confusa-type; see Kalb et al. 2000: 283). Hamathecium of richly branched and anastomosing, non-gelatinized paraphyses forming a reticulum around individual asci, I- Asci very elongate-cylindrical, I+ persistently dark blue throughout, with distinct, basally broad ocular chamber, I+ dark blue tholus without discernible structure and I+ blue outer wall (Sporopodiumtype; see Hafellner 1984: 277). Ascospores filiform, transversely multiseptate. Conidiomata not observed.

TyPE SPECIES: Bryogomphus caribaeus (W. R. Buck) Lücking, W. R. Buck, Sérus. \& L. I. Ferraro, comb. nov.; Gomphillus caribaeus W. R. Buck in Glenn et al., Lichenogr. Thomsoniana: 72. 1998.

Etymology. - The name of the new genus refers to the strong resemblance with the systematically unrelated genus Gomphillus [gomphus = nail] and its bryophilus habitat.

Bryogomphus is a remarkable new genus which combines features of several, partly unrelated, partly related genera (Table 1). The muscicolous growth, turbinate, vertically elongate apothecia and filiform, transversely multiseptate ascospores closely resemble Gomphillus, for which it was mistaken in its original description. The lecanoroid, amyloid asci, together with the apically disc-shaped apothecia, suggest placement in Bapalmuia and even possible synonymy with $B$. marginalis. However, the richly anastomosing, non-gelatinized paraphyses forming a reticulum around individual asci and the Sporopodium-type asci differ from all known species of Bapalmuia and closely related genera (e.g., Byssoloma, Fellhanera), which have rather indistinct, strongly coherent paraphyses (unbranched in Bapalmuia) and Byssoloma-type asci with $\mathrm{I}+$ darker tubular structure in the tholus (Kalb et al. 2000). Because of the coherent paraphyses, the entire hymenium reacts $\mathrm{I}+$ blue in these genera, while in Bryogomphus, only the asci are I+ persistently blue while the hamathecium is $\mathrm{I}-$. The hymenium therefore looks very characteristic when stained with Lugol, the asci being clearly visible as blue tubes between the reticulate, unstained paraphyses. This type of hymenium is more typical of genera such as Calopadia (paraphyses largely unbranched), Sporopodium (paraphyses anastomosing), and Tapellaria (paraphyses forming a reticulum around individual asci). However, these genera never produce filiform ascospores and have a paraplectenchymatous excipulum and a campylidial anamorph, as well as other differences (Lücking 1999; Vězda 1986).

FIGURE 1. Apothecial morphology in Bryogomphus, Gomphillus, and Bapalmuia. -A-D. Bryogomphus caribaeus (holotype). - E-F. Gomphillus calycioides (Chile). - G. Gomphillus ophiosporus, hydrated (Costa Rica). - H. Bapalmuia marginalis (holotype). - Scale $=1 \mathrm{~mm}$, except for B and D $(0.7 \mathrm{~mm})$ and $\mathrm{G}(2 \mathrm{~mm})$. 

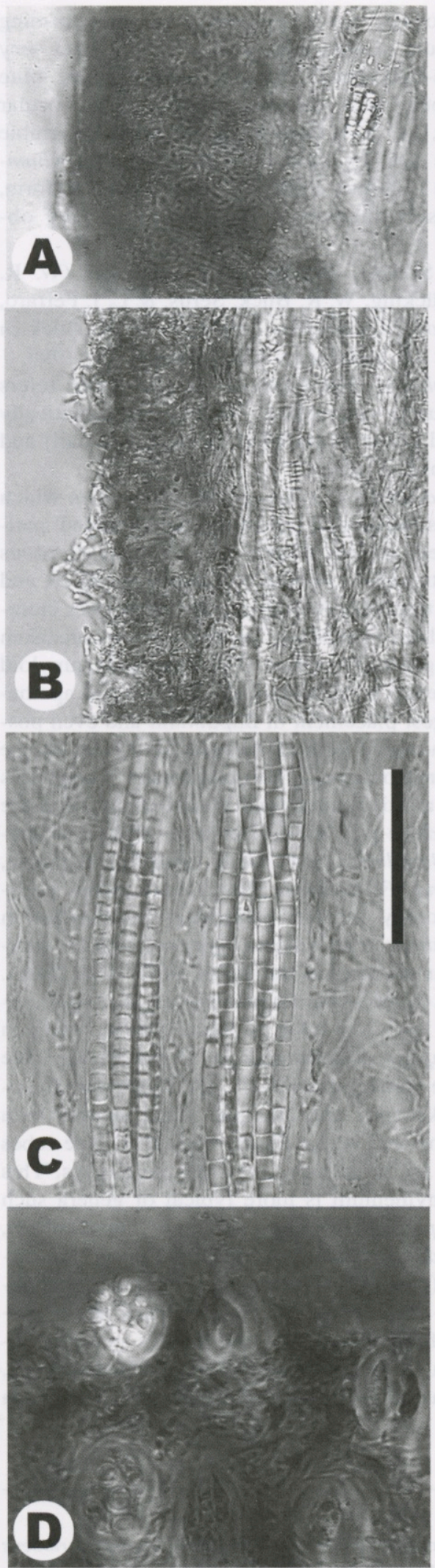
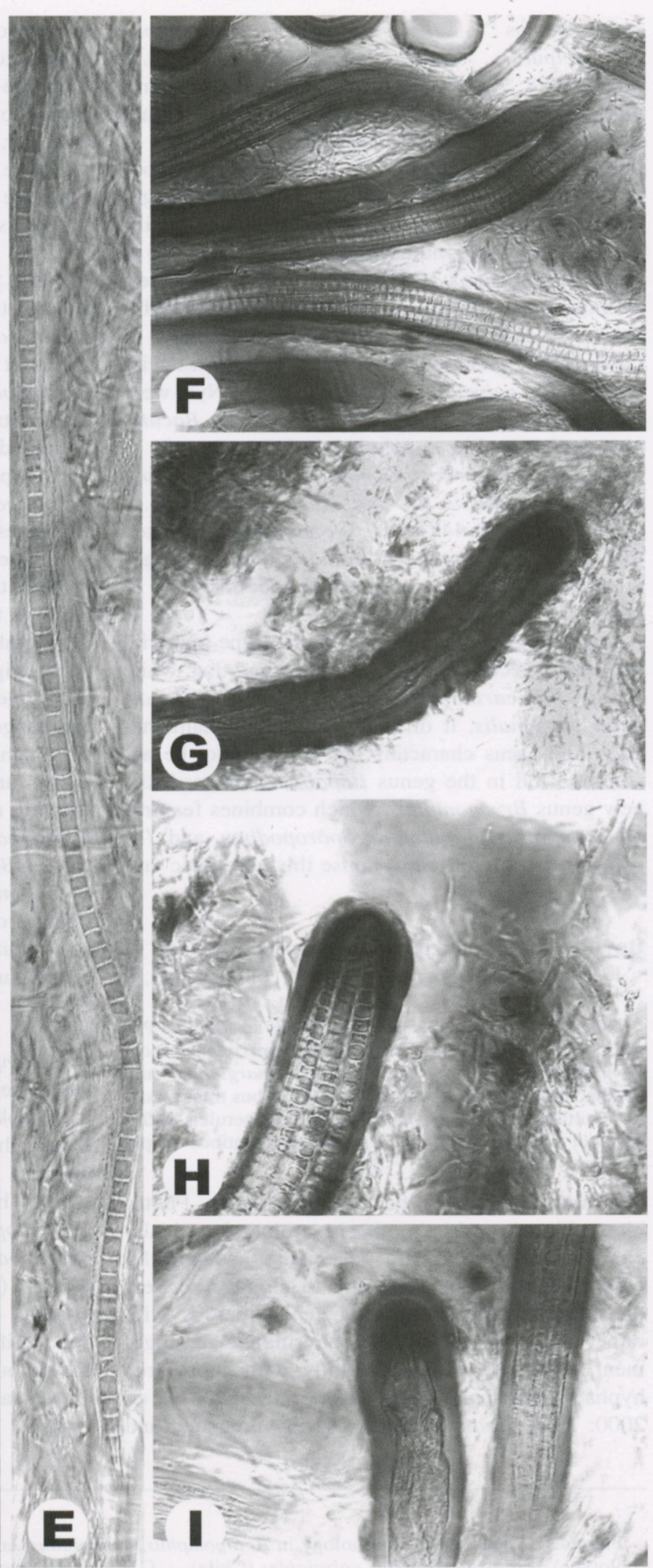
TABLE 1. Comparison of species with turbinate, vertically elongate apothecia and filiform, transversely multiseptate ascospores, in the three genera Gomphillus, Bryogomphus, and Bapalmuia.

\begin{tabular}{|c|c|c|c|}
\hline & Gomphillus calycioides & Bryogomphus caribaeus & Bapalmuia marginalis \\
\hline Family (Order) & Gomphillaceae (Ostropales) & Pilocarpaceae (Lecanorales) & Pilocarpaceae (Lecanorales) \\
\hline Thallus & $\begin{array}{l}\text { cartilaginous-corticate (Gyali- } \\
\text { deopsis-type) }\end{array}$ & $\begin{array}{l}\text { smooth-farinose-ecorticate } \\
\text { (Bapalmuia-type) }\end{array}$ & $\begin{array}{l}\text { smooth-farinose-ecorticate } \\
\text { (Bapalmuia-type) }\end{array}$ \\
\hline Photobiont & chlorococcoid (Trebouxia) & chlorococcoid (genus?) & chlorococcoid (genus?) \\
\hline Apothecia & $\begin{array}{l}\text { turbinate (vertically elongate) } \\
\text { with club-shaped top }\end{array}$ & $\begin{array}{l}\text { turbinate (vertically elongate) } \\
\text { with disc-shaped top }\end{array}$ & $\begin{array}{l}\text { turbinate (vertically elongate) } \\
\text { with disc-shaped top }\end{array}$ \\
\hline Excipulum & hyphal (Gyalideopsis-type) & $\begin{array}{l}\text { psoroplectenchymatous ( } \mathrm{Ba} \text { - } \\
\text { palmuia-type) }\end{array}$ & $\begin{array}{l}\text { psoroplectenchymatous ( } \mathrm{Ba} \text { - } \\
\text { palmuia-type) }\end{array}$ \\
\hline Hamathecium & $\begin{array}{l}\text { anastomosing, I--, strongly ge- } \\
\text { latinized (Gyalideopsis } \\
\text { type) }\end{array}$ & $\begin{array}{l}\text { anastomosing, I-, non-gelati- } \\
\text { nized (Tapellaria type) }\end{array}$ & $\begin{array}{l}\text { unbranched, I+, gelatinized } \\
\text { (coherent) (Bapalmuia type) }\end{array}$ \\
\hline Asci & $\begin{array}{l}\text { annelasceous, I- (Gyalideop- } \\
\text { sis-type) }\end{array}$ & $\begin{array}{l}\text { lecanoroid, I+ blue (Sporopo- } \\
\text { dium-type) }\end{array}$ & $\begin{array}{l}\text { lecanoroid, } \mathrm{I}+\text { blue (Byssolo- } \\
\text { ma-type) }\end{array}$ \\
\hline Ascospores & $\begin{array}{l}\text { filiform, multiseptate } 200-350 \\
\quad \times 2-3.5 \mu \mathrm{m}\end{array}$ & $\begin{array}{l}\text { filiform, multiseptate } 300-400 \\
\quad \times 3-5 \mu \mathrm{m}\end{array}$ & $\begin{array}{l}\text { filiform, multiseptate } 300-500 \\
\quad \times 2-2.5 \mu \mathrm{m}\end{array}$ \\
\hline
\end{tabular}

Remarkably enough, there is a muscicolous species described as Lecidea turbinata (Tuckerman 1864) [ [ Lopadium turbinatum (Tuck.) Zahlbr.] that actually belongs in Calopadia [Calopadia turbinata (Tuck.) Sérus. \& Lücking, comb. nov.; Lecidea turbinata Tuck., Proc. Amer. Acad. Arts 6: 282. 1864]. Its apothecia are somewhat similar to those of Bryogomphus but less elongate, its excipulum and paraphyses are of the Calopadia type, and its ascospores are muriform and frequently remain partly extruded on the apothecial disc and then disintegrate into numerous very small conidia. It is thus clear that the two taxa are not congeneric, although belonging in the same family. Calopadia turbinata, originally also described from Cuba, has been found abundantly over mosses in montane rain forests of Costa Rica in the frame of the TICOLICHEN project (Lücking et al. 2004), as well as in the Lesser Antilles (St. Lucia and Guadeloupe: Basse-Terre).

The Pilocarpaceae have recently been emended to include the Micareaceae and Ectolechiaceae (Andersen \& Ekman 2004), with a large number of genera and many enigmatic taxa, such as Roccellinastrum Follmann (Follmann 1967; Henssen et al. 1982; Kantvilas 1990) and Sczcawinskia Funk (Holien \& Tønsberg 2002), growing in sheltered situations and thus not easily and frequently collected. It is therefore not surprising to discover a new genus growing over bryophytes.

The analogies between Bryogomphus and Gom- phillus are indeed amazing and not just restricted to the muscicolous growth and the turbinate, vertically elongate apothecia. Even apothecial sections look extremely similar at first glance, and some of the differences, such as the prosoplectenchymatous, externally thinly byssoid excipulum are easily overlooked or attributed to infrageneric variation; many Gomphillaceae do indeed have a prosoplectenchymatous excipulum, although different in structure (Lücking 1997; Lücking et al. 2005). In addition to the slight differences in the appearance of the paraphyses and asci, the two taxa can easily be separated by the I-reaction: negative in Gomphillus, but with the asci quickly turning deep blue in Bryogomphus.

Another genus with turbinate apothecia and filiform ascospores is Conotremopsis Vězda (1977), known from Tasmania and New Zealand (Kantvilas \& Jarman 1999) and recently found in La Réunion in the Indian Ocean (Kalb 2004). It differs by its byssoid thallus, lichenized with Trentepohlia, and its Ostropales-type apothecia; it is presently placed in Stictidaceae (Eriksson 2005).

In its original description as Gomphillus caribaeus (Buck 1998: 72), the ascospores of Bryogomphus caribaeus are given as 5-7 $\mu \mathrm{m}$ broad. We revised the three collections cited in the protologue and found that the ascospores are narrower (3-5 $\mu \mathrm{m})$ and resemble those of Gomphillus calycioides (FIG. 1E-F). Interestingly, all three collections were first identified as $G$. calycioides, and it was the sup-

FIGURE 2. Apothecial anatomy in Bryogomphus caribaeus (holotype). - A-B. Lateral excipulum; note the labyrinthical structure in A and the external byssoid hyphae in B. - C-E. Asci with ascospores and single ascospore. -F-I. Asci stained in Lugol's solution; note the unstained, richly anastomosing paraphyses and the uniformely dark tholus with lateral flanks and ocular chamber $(\mathrm{oc}) .-$ Scale $=40 \mu \mathrm{m}$, except for $\mathrm{A}-\mathrm{B}(60 \mu \mathrm{m}), \mathrm{F}(80 \mu \mathrm{m})$, and $\mathrm{G}$ and I $(50 \mu \mathrm{m})$. 
posedly broader ascospores that triggered the description of the new species. Had the original identification as $G$. calycioides been maintained, we would probably have never discovered this enigmatic genus. To make things even more complicated, the type collection of Gomphillus (Bryogomphus) caribaeus also contains a small specimen of Gomphillus ophiosporus (FIG. 1G) with several apothecia; the two are well separated on different areas of the phorophyte moss and easily distinguished morphologically.

Specimens of Bryogomphus caribaeus examined (in addition to those cited by Buck 1998: 72).-LESSER ANTILLES. GuAdELOUPE: Basse-Terre, NW of La Soufrière, along Victor Hughues track starting at forest house of Matouba, slightly disturbed forest and plantations, 800-1,000 $\mathrm{m}$, on terricolous mosses and on mossy trunk, April 1995 and March 1996, Sérusiaux s.n. (LG).

Specimens of Calopadia turbinata examined.-CUBA. Unknown locality, invading the thallus of Coccocarpia erythroxyli, Wright 2 [with the annotation "illegible"] (FH, holotype!). LESSER ANTILLES. ST. LUCIA: Quilesse Forest, near interpretation center, undisturbed forest with Heliconia and Cyathea, 300-350 m, on tree, February 1993, Sérusiaux s.n. (LG). GuAdEloupe: Basse-Terre, La Grande Traversée road, track between Col des Mamelles and Morne Léger, slightly disturbed humid forest, $600 \mathrm{~m}$, on mossy tree, March 1996, Sérusiaux s.n. (LG); ibid., S of Saint-Rose, track starting at the sulfur spring of Sofaia, little disturbed forest, $450 \mathrm{~m}$, on mossy tree, April 1995, Sérusiaux s.n. (LG).

\section{ACKNOWLEDGMENTS}

The collection trips during which the material of Bryogomphus was collected was financed with a grant from the NSF for a project Moss Flora of the West Indies to WRB. ES thanks the curator of the Farlow Herbarium (FH) for the loan of the type material of Lecidea turbinata and the authorities of the Parc National de la Guadeloupe for the permit to collect lichens in the park.

\section{Literature Cited}

Andersen, H. L. \& S. Ekman. 2004. Phylogeny of the Micareaceae inferred from nrSSU DNA sequences. Lichenologist 36: 27-35.

Buck, W. R. 1998. Lichen flora of eastern North America: the genus Gomphillus (Gomphillaceae), pp. 71-76. In M. G. Glenn, R. C. Harris, R. Dirig \& M. S. Cole (eds.) Lichenographia Thomsoniana: North American Lichenology in Honor of John W. Thomson. Mycotaxon Ltd., Ithaca, NY.

ERIKSSON, O. E. (ED.) 2005. Outline of Ascomycota2005. Myconet 11: 1-113.

EssLinger, T. L. 1975. A new North American species of the lichen genus Gomphillus. Mycotaxon 1: 189-192.

Ferraro, L. I. \& R. LüCKING. 2005. The genus Gomphillus (Ostropales: Gomphillaceae) in the Americas, with the new species Gomphillus pedersenii from Argentina. THE BRYOlogist 108: 491-496.

FollmanN, G. 1967. Die Flechtenflora der nordchilenischen Nebeloase Cerro Moreno. Nova Hedwigia 14: 215281.

HAFellner, J. 1984. Studien in Richtung einer natürlicheren Gliederung der Sammelfamilien Lecanoraceae und Lecideaceae. Beiheft zur Nova Hedwigia 79: 241-371.

Henssen, A., G. Vobis \& B. Renner. 1982. New species of Roccellinastrum with an emendation of the genus. Nordic Journal of Botany 2: 587-599.

Holien, H. \& T. Tønsberg. 2002. Two new species in the lichen genus Szczawinskia A. Funk. Lichenologist 34: 369-372.

KALB, K. 2004. New or otherwise interesting lichens II. Bibliotheca Lichenologica 88: 301-329.

- \& A. VĚZDA. 1988. Neue oder bemerkenswerte Arten der Flechtenfamilie Gomphillaceae in der Neotropis. Bibliotheca Lichenologica 29: 1-80.

- R. LüCKING \& E. SÉruSIAUX. 2000. Studies in Bacidia sensu lato (lichenized Ascomycetes: Lecanorales). I. The genus Bapalmuia. Mycotaxon 75: 281309.

Kantvilas, G. 1990. The genus Roccellinastrum in Tasmania. Lichenologist 22: 79-86.

- \& S. J. JARMAN. 1999. Lichens of rainforest in Tasmania and south-eastern Australia. Flora of Australia Supplementary Series 9: 1-212.

LÜCKING, R. 1997. Additions and corrections to the knowledge of the foliicolous lichen flora of Costa Rica. The family Gomphillaceae. Bibliotheca Lichenologica 65: 1-109.

1999. Ergänzungen und Verbesserungen zur Kenntnis der foliikolen Flechtenflora Costa Ricas. Die Familie Ectolechiaceae. Phyton (Horn) 39: 131-165.

, H. J. M. SipMan \& L. UMAÑa Tenorio. 2004. TICOLICHEN-The Costa Rican lichen biodiversity inventory as a model for lichen inventories in the tropics. The $5^{\text {th }}$ IAL Symposium Lichens in Focus, August 2004, Tartu (Estonia). Posterabstracts.

, E. SÉrusiaux \& A. VĚzdA. 2005. Phylogeny and systematics of the lichen family Gomphillaceae (Ostropales) inferred from cladistic analysis of phenotype data. Lichenologist 37: 123-170.

SANTESSON, R. 1952. Foliicolous lichens I. A revision of the taxonomy of the obligately foliicolous, lichenized fungi. Symbolae Botanicae Upsalienses 12 (1): 1-590.

SÉrusiaux, E. 1993. New taxa of foliicolous lichens from western Europe and Macaronesia. Nordic Journal of Botany 13: 447-461.

TUCKERMAN, E. 1864. Observationes lichenologicae. Observations on North American and other lichens. Proceedings of the American Academy of Arts and Sciences 6: 263-287.

VĚZDA, A. 1977. Flechtensystematische Studien X. Contremopsis weberiana gen. novum et $\mathrm{sp}$. nova, eine neue Flechte aus der Familie Ostropaceae. Folia Geobotanica Phytotaxonomica 12: 313-316.

1986. Neue Gattungen der Familie Lecideaceae s. lat. (Lichenes). Folia Geobotanica et Phytotaxonomica 21: 199-219.

ms. received May 24, 2005; accepted July 282005. 


\title{
Gomphillus morchelloides (Ostropales: Gomphillaceae), A New Lichen Species from Chile and Papua New Guinea
}

\author{
ROBERT LÜCKING \\ Department of Botany, The Field Museum, 1400 South Lake Shore Drive, Chicago, IL 60605-2496, U.S.A. \\ e-mail: rlucking@fieldmuseum.org \\ EMMANUËL SÉRUSIAUX \\ Plant Taxonomy \& Conservation Biology Unit, University of Liège, Sart Tilman B22, B-4000 Liège, Belgium; \\ e-mail: e.serusiaux@ulg.ac.be
}

Abstract. Revision of two collections of Gomphillus from Papua New Guinea and Chile, previously identified as Gomphillus ophiosporus and $\mathrm{G}$. calycioides, respectively, revealed that these represent an undescribed species, G. morchelloides Lücking \& Sérus. The new species is characterized by short-stipitate, apically much broadened, cerebriform to morchelloid apothecia and ascospores intermediate between those of $\mathrm{G}$. ophiosporus and $\mathrm{G}$. calycioides.

Keywords. Gomphillus, muscicolous, Chile, Papua New Guinea, new species.

During a revision of material of Gomphillus collected by Henry A. Imshaug in the West Indies and southern South America, we came across a peculiar collection of Gomphillus with cerebriform apothecia with an irregularly foveolate surface that very much resembles a tiny Morchella. Since the ascospores of that material were not very well developed, we first considered this to be a postmature or unhealthy form of the widespread G. calycioides (Del. ex Duby) Nyl. However, exactly the same morphological features were observed in a collection from Papua New Guinea, which had previously been identified as an age-related aberrant form of $G$. ophiosporus Kalb \& Vězda (Aptroot et al. 1997). The latter collection has well-developed, healthy ascospores, and sections of the apothecia revealed that the "folds" are not caused by shrunken, old parts of the hymenium, as one would suspect if this were a developmental artifact, but by prosoplectenchymatous projections of the inner, strongly pigmented part of the excipulum ("inverse columellae'). Also, no other of the nearly 300 species in Gomphillaceae shows similar deformations in postmature apothecia (Lücking et al. 2005), and therefore we interpret this character as specific and establish the new species, $G$. morchelloides Lücking \& Sérus., for this taxon. The genus Gomphillus thus comprises five species (Buck 1998; Esslinger 1975; Ferraro \& Lücking 2005; Kalb \& Vězda 1988; Lücking et al. 2005b); for an updated key see Ferraro and Lücking (2005).

\section{THE NEW SPECIES}

GOMPHILLUS MORCHELlOIDES Lücking \& Sérus., sp. nov.

FIGS. 1-2

Apothecia fusco-nigra, superficie foveolata apothecio Morchellae simile; ascospori 2.0-3.0 $\mu \mathrm{m}$ lati; hyphophori non visi.

Type: PAPUA NEW GUINEA. Central ProvINCE: Owen Stanley Range, Myola, 2,700 m, on tree fern, 12 Mar 1986, Lambley 40/86 (holotype: BM).

Thallus muscicolous over bark (in type material on tree fern), very thin, gray-white, smooth to somewhat irregular. Apothecia short-stipitate and vertically elongate, clavate to broadly club-shaped when mature, 0.3-0.6 mm diam. at the top and 0.5$1.0 \mathrm{~mm}$ high, light brown at the base and brownish black above, with smooth surface when young but upper part soon becoming irregularly foveolate and resembling a tiny Morchella. Excipulum hyphal to prosoplectenchymatous, 20-40 $\mu \mathrm{m}$ broad, orange brown in inner parts and colorless at the periphery; pigmented inner parts forming irregular projections causing the foveolate surface (in sections resembling "inverse columellae"). Hymenium 400-700 $\mu \mathrm{m}$ high. Paraphyses thin, branched and anastomosing. Asci cylindrical, 300-500 × 14-18 $\mu \mathrm{m}$. Ascospores 8 per ascus, slightly and irregularly twisted, filiform, transversally multiseptate, 300$400 \times 2.0-3.0 \mu \mathrm{m}$, colorless. Hyphophores not observed.

Additional specimen examined.-CHILE. Magallanes, 1969, Imshaug \& Ohlsson 43151 (MSC). 

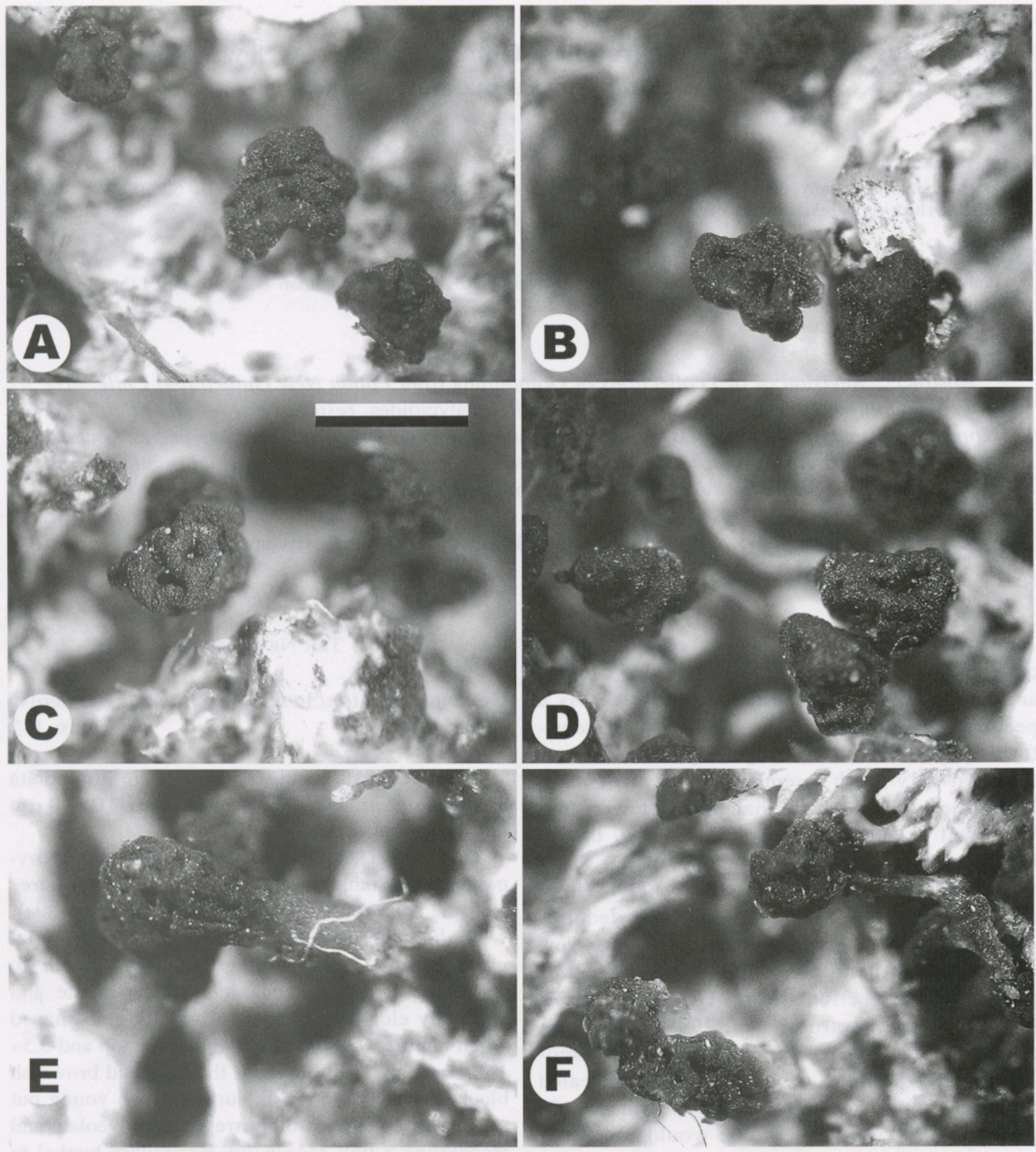

FIGURE 1. Apothecial morphology of Gomphillus morchelloides. - A-D. Holotype (Papua New Guinea). - E-F. Paratype (Chile). - Scale $=1 \mathrm{~mm}$.

Etymology.-The apothecia of this new species very much resemble tiny apothecia of Morchella in the Pezizales.

Gomphillus morchelloides is easily recognized by its cerebriform, morchelloid apothecia; all other species of the genus have apothecia with smooth surface (Buck 1998; Esslinger 1975; Ferraro \& Lücking 2005; Kalb \& Vězda 1988). At first glance, the apothecia of the new species make the impression of being postmature or un- healthy and an aberrant form of another species, such as $G$. calycioides. However, the following observations confirm that the morchelloid apothecia is a good, specific character worth being recognized at the species level: (1) the cerebriform apothecial surface is not caused by folds of old hymenium parts but by projections of the inner, pigmented part of the excipulum; (2) the type material produces sound, mature hymenia with well-developed ascospores; (3) the ascospores 

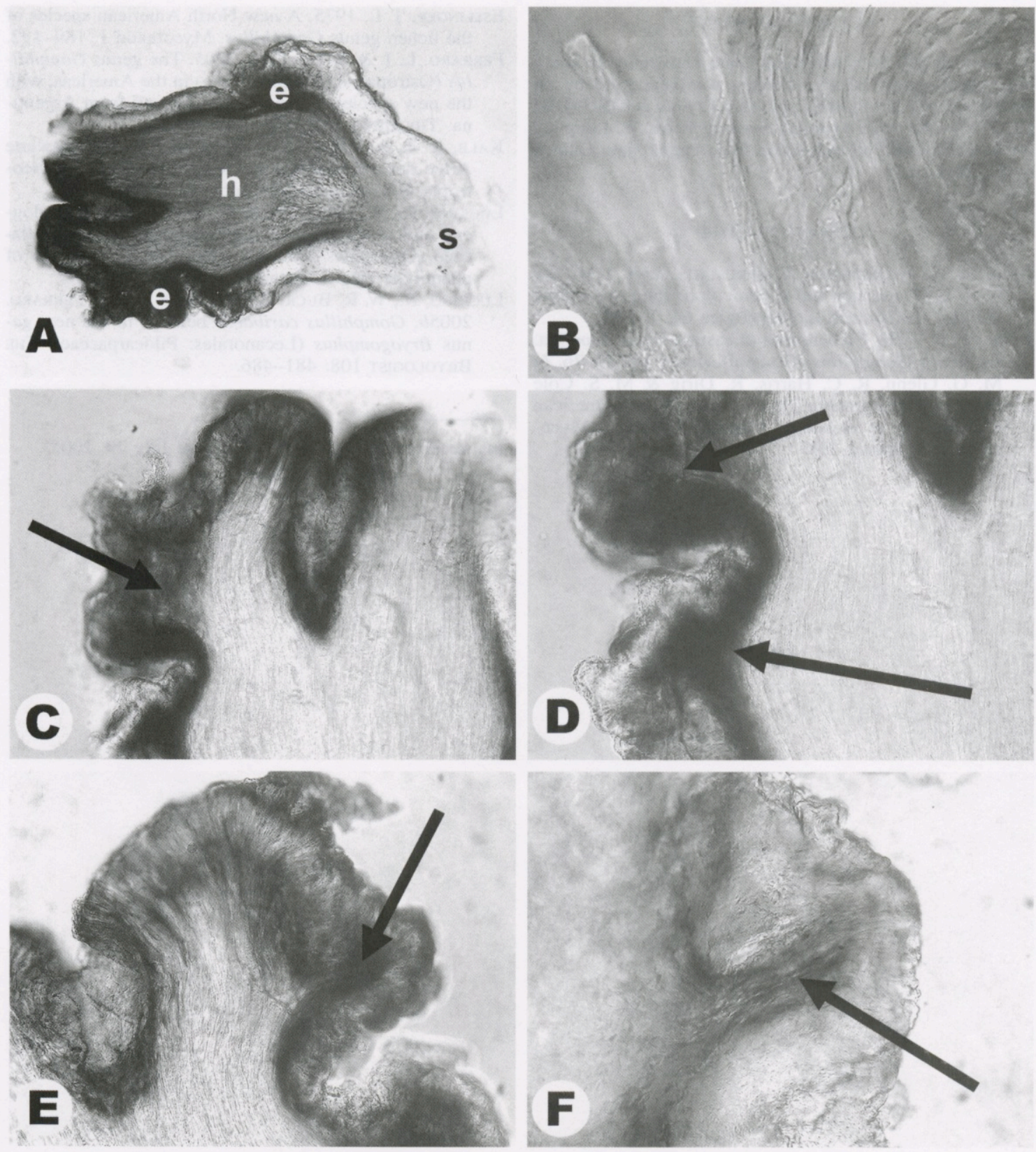

FIGURE 2. Apothecial anatomy of Gomphillus morchelloides (all holotype). - A. Vertical section through apothecium, showing basal stipe (s), excipulum with irregular outgrowths of pigmented inner part (e), and hymenium (h). B. Ascus with bundle of slightly spirally arranged ascospores. - C-F. Vertical and transversal sections of apothecia showing excipulum with irregular outgrowths of pigmented inner part (arrows). - Scale $=50 \mu \mathrm{m}$.

are intermediate between those of $G$. calycioides and $G$. ophiosporus; and (4) no other species of Gomphillaceae produces apothecia with a cerebriform surface, which would be expected if this were caused by reaching postmaturity or otherwise being unhealthy.

The short-stipitate, apically much broadened apothecia somewhat recall those of Gomphillus americanus Essl., but that species has a smooth apothecial surface and a weakly pigmented excipulum, and hyphophores are often present.

The new species is known from two collections, one in the upper montane rain forest in Papua New Guinea, and the other in the southern part of Chile, which indicates preferences for cool-temperate climates. 


\section{ACKNOWLEDGMENTS}

The visit of RL to Michigan State University to study the collections of Henry Imshaug was supported by an NSF grant to Alan Prather and Alan Fryday at MSU (DBI 0237401). We wish to thank warmly Peter W. Lambley for having placed his collection from Papua New Guinea at our disposal.

\section{Literature Cited}

Aptroot, A., P. Diederich, E. Sérusiaux, \& H. J. M. SipMAN. 1997. Lichens and lichenicolous fungi from New Guinea. Bibliotheca Lichenologica 64: 1-220.

BuCK, W. R. 1998. Lichen flora of eastern North America: the genus Gomphillus (Gomphillaceae), pp. 71-76. In M. G. Glenn, R. C. Harris, R. Dirig \& M. S. Cole (eds.), Lichenographia Thomsoniana: North American Lichenology in Honor of John W. Thomson. Mycotaxon Ltd., Ithaca, NY.
Esslinger, T. L. 1975. A new North American species of the lichen genus Gomphillus. Mycotaxon 1: 189-192.

FerRaro, L. I. \& R. LÜCKING. 2005. The genus Gomphillus (Ostropales: Gomphillaceae) in the Americas, with the new species Gomphillus pedersenii from Argentina. THE BRYOLOGIST 108: 491-496.

KALB, K. \& A. VĚZDA. 1988. Neue oder bemerkenswerte Arten der Flechtenfamilie Gomphillaceae in der Neotropis. Bibliotheca Lichenologica 29: 1-80.

LÜCKING, R., E. SÉRusiaux \& A. VĚzdA. 2005a. Phylogeny and systematics of the lichen family Gomphillaceae (Ostropales) inferred from cladistic analysis of phenotype data. Lichenologist 37: 123-170.

Lücking, R., W. R. Buck, E. Sérusiaux \& L. I. Ferraro. $2005 b$. Gomphillus caribaeus belongs in the new genus Bryogomphus (Lecanorales: Pilocarpaceae). THE BRYOLOGIST 108: 481-486.

ms. received June 22, 2005; accepted July 29, 2005. 


\title{
The Genus Gomphillus (Ostropales: Gomphillaceae) in the Americas, with the New Species Gomphillus pedersenii from Argentina
}

\author{
Lidia I. FerRARO \\ Instituto de Botanica del Nordeste (IBONE), Sargento Cabral 2131,3400 Corrientes, Argentina; e-mail: Iferraro@ \\ agr.unne.edu.ar \\ ROBERT LÜCKING \\ Department of Botany, The Field Museum, 1400 South Lake Shore Drive, Chicago, IL 60605-2496, U.S.A. \\ e-mail: rlucking@ fieldmuseum.org
}

\begin{abstract}
A synopsis of the genus Gomphillus in the Americas is presented, with the description of the new species, G. pedersenii L. I. Ferraro \& Lücking, from Argentina. The new species is characterized by pale, vertically elongate apothecia, rather broad ascospores, and umbelliform hyphophores. With the exclusion of G. caribaeus W. R. Buck, which belongs in a new genus, Bryogomphus, in the Pilocarpaceae, and the recent discovery of another new species, G. morchelloides Lücking \& Sérus., the genus Gomphillus now comprises five species. All taxa are keyed out and briefly discussed, and a distribution map for the Americas is given.
\end{abstract}

Keywords. Gomphillus, Brazil, Chile, Costa Rica, Cuba, Ecuador, Jamaica, Puerto Rico, United States, muscicolous.

The genus Gomphillus Nyl. was first described to accommodate an enigmatic lichen with vertically elongate apothecia, G. calycioides (Del. ex Duby) Nyl., rare but widespread in oceanic parts of western Europe. That species had originally been described in the genus Baeomyces and was also later frequently related to lichens with stipitate or podetiate apothecia (Duvigneaud 1944; Räsänen 1943; Zahlbruckner 1926), although differing clearly in apothecial anatomy (Santesson 1952). Watson (1929) was the first to accommodate Gomphillus in the separate family Gomphillaceae, which was later validated by Hafellner (1984). Vězda and Poelt (1987) established that the "postmature apothecia" described from a second species, G. americanus Essl. (Esslinger 1975), were in fact hyphophores, and emended the family Gomphillaceae to include all species with hyphophores previously assigned to Asterothyriaceae. This was supported by additional characters shared between Gomphillus and these other genera, such as excipulum and hamathecium structure, ascus type, and thallus structure.

Hafellner $(1984,1988)$ considered the ascus of Gomphillus to be fissitunicate and established the order Gomphillales [nom. nud.] for the family. Vězda and Poelt (1987) supported the view of the asci of Gomphillaceae as being fissitunicate, but Lücking (1997) assigned them to the annellasceous type typical of Ostropales and suggested that the seemingly fissitunicate asci of Gomphillus might merely be an observational artifact due to the fact that they are extremely elongate. The position of Gomphillus and the Gomphillaceae within the Ostropales was recently confirmed using a molecular approach (Lücking et al. 2004), and phenotype-based phylogenetic analyses suggests Gomphillus to be derived from a Gyalideopsis-like ancestor (Dennetière \& Péroni 1998; Lücking et al. 2005a).

Thus far, Gomphillus comprised four species (Esslinger 1975; Kalb \& Vězda 1988; Buck 1998; Lücking et al. 2005a), characterized by dark brown, vertically elongate or stipitate apothecia with filiform, transversely multiseptate ascospores and umbelliform hyphophores (only known from G. americanus). Upon restudy of the original material, one of these, G. caribaeus, had to be excluded from the genus and is now placed in a new genus, Bryogomphus, in the Pilocarpaceae (Lücking et al. 2005b). Also, a new species with Morchella-like, cerebriform apothecia was discovered in material from Papua New Guinea and Chile (Lücking \& Sérusiaux 2005). During an ongoing survey of Gomphillaceae in northern Argentina and adjacent areas (Ferraro 2000, 2004; Ferraro \& Lücking 2003; Ferraro et al. 2001; Ferraro \& Vězda 1989), the first author discovered another species of Gomphillus that differs by its pale instead of dark apothecia; it is the second species of the genus that produces hyphophores. This new species, G. pedersenii, is described in this paper, and a synopsis of the genus in the Americas is given. 

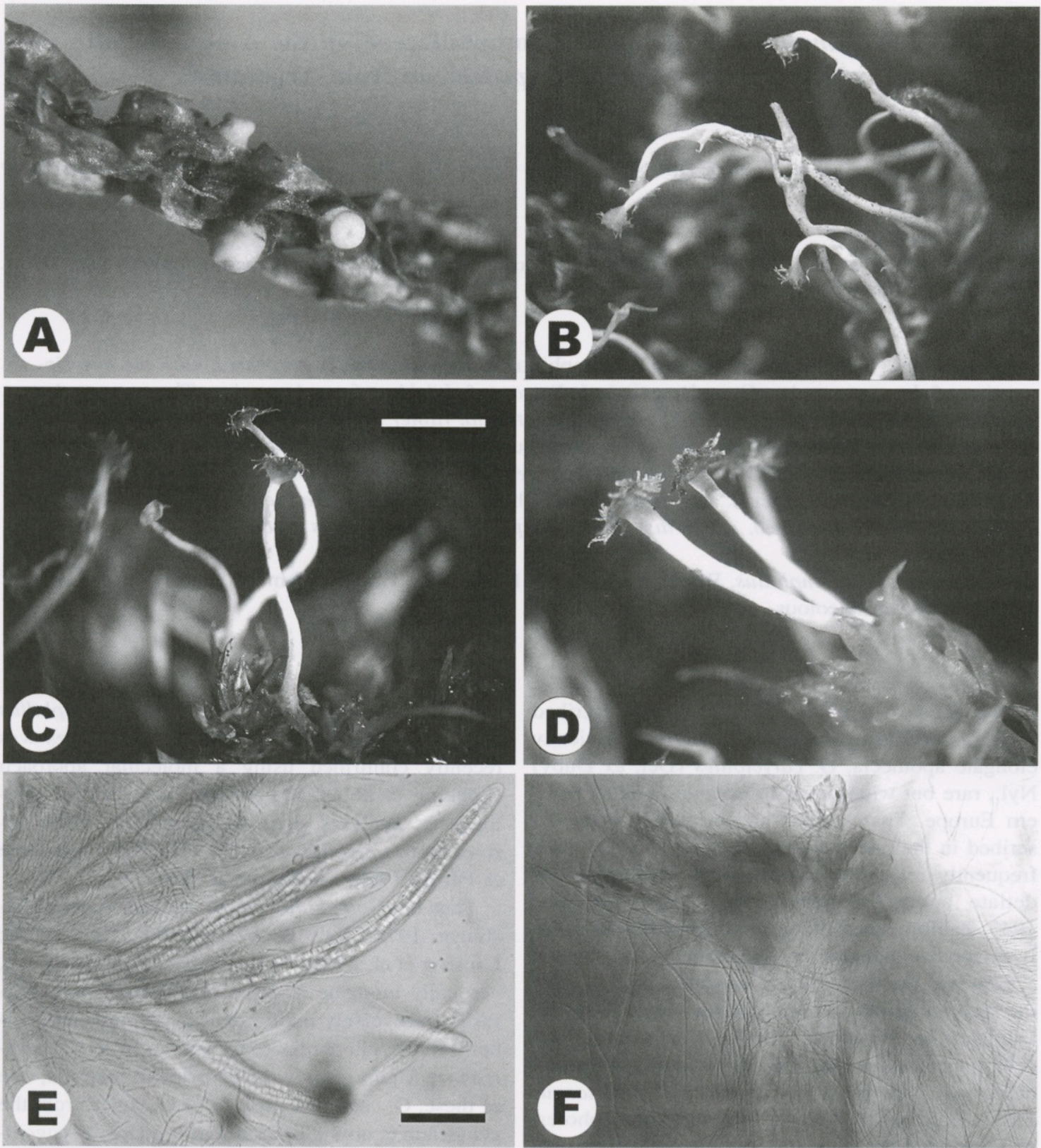

FIGURE 1. Morphology and anatomy of Gomphillus pedersenii (holotype). - A. Apothecia. - B-D. Hyphophores. -E. Asci with ascospores and paraphyses. - F. Apical portion of hyphophore with conidia. - Macroscopic scale for $\mathrm{A}$ and $\mathrm{B}=1 \mathrm{~mm}$, for $\mathrm{C}=0.75 \mathrm{~mm}$, for $\mathrm{D}=0.5 \mathrm{~mm}$; microscopic scale for $\mathrm{E}$ and $\mathrm{F}=50 \mu \mathrm{m}$.

THE New Species

\section{GOMPHILLUS PEDERSENII Ferraro \& Lücking, $s p$.} nov.

FIG. 1

Apothecia flavo-alba; ascospori $2.0-2.5 \mu \mathrm{m}$ lati; hyphophori umbelliformes, parte apicali peltati lobulis triangularibus instructi.

Type: ARGENTINA. Salta. El Rey National Park, cloud forest, in forest aisle, trail to Pozo
Verde, over mosses on canopy branches of fallen tree, 11 March 2005, Ferraro \& Popoff 7901 (CTES, holotype; $\mathrm{F}$, isotype).

Thallus muscicolous over bark (fallen canopy branches), very thin, pale greenish, smooth to weakly verrucose. Apothecia sessile and vertically elongate, stout-cylindrical to barrel-shaped, 0.3-0.5 $\mathrm{mm}$ diam. and $0.4-0.8 \mathrm{~mm}$ high, yellowish white. Excipulum hyphal, 20-30 $\mu \mathrm{m}$ broad, colorless. $\mathrm{Hy}$ menium 300-600 $\mu \mathrm{m}$ high. Paraphyses thin, 
branched and anastomosing. Asci cylindrical, 250$400 \times 14-18 \mu \mathrm{m}$. Ascospores 8 per ascus, in a straight bundle or slightly and irregularly twisted, filiform, transversally multiseptate, 250-300 $\times$ 2.5-4.0 $\mu \mathrm{m}$, colorless. Hyphophores narrowly umbelliform, very rarely branched at the base, 5-10 $\mathrm{mm}$ high, with pale stipe and dark brown, to 0.3 $\mathrm{mm}$ broad, peltate-denticulate apex formed by acute, triangular lobes. Diahyphae filiform, transversally multiseptate, $150-200 \times 1.0-1.5 \mu \mathrm{m}$.

Additional specimen examined.-ARGENTINA. SALTA: El Rey National Park, at the entrance of Los Lobitos trail towards the waterfall, over mosses in forest understory, 12 March 2005, Ferraro \& Popoff 7972 (CTES).

Etymology.-This new species is dedicated to Dr. Myndel Pedersen and the Myndel Botanical Foundation, for supporting collection trips of Latin American taxonomists, on one of which the new species was discovered.

Gomphillus pedersenii exhibits the typical apothecial morphology and anatomy of the genus, with vertically elongate apothecia and filiform, transversally multiseptate ascospores. It is the second species in the genus found with hyphophores, and the hyphophores conform perfectly to the Gomphillus type (see Buck 1998; Vězda \& Poelt 1987).

The new species differs from the other species known so far by its yellowish white instead of dark brown apothecia. Indeed, at first glance the apothecia of Gomphillus pedersenii closely resemble the perithecia of certain Aspidothelium species, such as A. macrosporum and A. papilliferum. The ascospores are most similar to those of the type species, Gomphillus calycioides, although slightly larger. Hyphophores have so far only been described from $G$. americanus, which differs from $G$. pedersenii by its dark brown, stipitate rather than vertically elongate apothecia, and its shorter, thinner ascospores which are spirally twisted within the asci (Buck 1998; Esslinger 1975). The hyphophores of $G$. americanus are very similar in shape but larger (Buck 1998).

Because of its stipitate rather than vertically elongate apothecia, and because being the only species to produce hyphophores, Buck (1998) considered Gomphillus americanus as somewhat isolated within the genus and even possibly deserving separate generic status. The discovery of $G$. pedersenii supports the unity of the species known so far, since it combines vertically elongate apothecia similar to those of G. calycioides and G. ophiosporus with the hyphophores typical of $G$. americanus. This is also confirmed by a phenotype-based phylogenetic analysis, which strongly supports G. americanus, G. calycioides, and $G$. ophiosporus, as monophyletic clade (Lücking et al. 2005a).
Gomphillus pedersenii was first found over mosses on canopy branches of a fallen tree in a montane cloud forest in El Rey National Park, with trees being to $30 \mathrm{~m}$ high, with abundant lianas and epiphytes, and an annual precipitation of 700-1,000 $\mathrm{mm}$. This suggests that species of Gomphillus might be commonly found on epiphytic bryophytes in the canopy of tropical montane rainforests, a habitat that is rarely collected for lichens.

\section{Key to THE SPECIES OF Gomphillus}

1. Apothecia pale yellowish white; hyphophores present, to $10 \mathrm{~mm}$ high; southern South America (Argentina) _... Gomphillus pedersenii

1. Apothecia dark brown; hyphophores absent or present and then to $20 \mathrm{~mm}$ high …_._. 2

2. Apothecia cerebriform, with irregularly foveolate surface resembling a tiny Morchella; southern South America (Chile) and Papua New Guinea _._..... Gomphillus morchelloides 2. Apothecia with smooth surface

3. Apothecia stipitate, thinly pruinose; hyphophores present; southeastern North America (U.S.A.) and southern South America (Argentina)

\section{Gomphillus americanus}

3. Apothecia vertically elongate, non-pruinose; hyphophores absent

4. Ascospores $350-500 \times 1.5-2.0 \mu \mathrm{m}, 200-250$ times as long as broad, strongly spirally twisted within the asci; Neotropics (Central and South America, West Indies)

Gomphillus ophiosporus

4. Ascospores $200-350 \times 2-4 \mu \mathrm{m}, 100-150$ times as long as broad, straight or slightly and irregularly twisted within the asci; southeastern North America (U.S.A.), southern South America (Chile) and western Europe

Gomphillus calycioides

\section{Notes on the Other SPECIES OF Gomphillus}

A restudy of the type material and the other collections cited in the protologue of Gomphillus caribaeus W. R. Buck revealed that this taxon does not belong in Gomphillaceae but is a member of the Pilocarpaceae. Its apothecia are very similar to those of Bapalmuia marginalis (Kalb et al. 2000), its asci are lecanoroid and of the Sporopodium-type sensu Hafellner (1984), and its paraphyses are very similar to those of Tapellaria (Santesson 1952). The new genus Bryogomphus is described for this taxon (Lücking et al. 2005b).

The genus Gomphillus thus contains five species, all of which have been reported from the Americas (FIG. 2). Only the type species, G. calycioides, and the other new species, G. morchelloides, are known outside the Americas. The five species have very distinctive distribution ranges: while G. ophiosporus is only known from the Neotropics and so far the only species known from that area, the other four occur in the temperate zones in either both $(G$. 


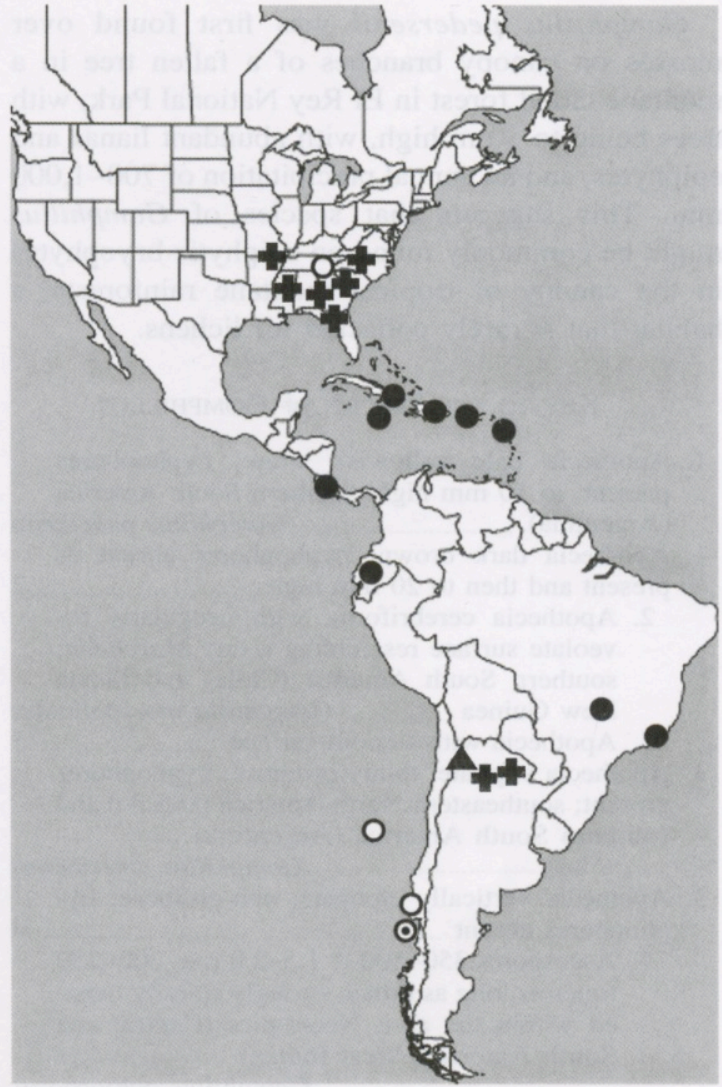

FIGURE 2. Distribution of species of Gomphillus in the Americas. Black dots $=G$. ophiosporus, black circles with white center $=G$. calycioides, black crosses $=G$. americanus, black triangle $=G$. pedersenii, circle with black dot $=G$. morchelloides

calycioides and $G$. americanus) or in the Southern Hemisphere only (G. morchelloides, G. pedersenii).

Gomphillus americanus Essl., Mycotaxon 1: 189 (1975). Type. U.S.A., Esslinger 3184A (holotype: us; isotype: DUKE).

Diagnostic characters.-Apothecia stipitate, dark brown; ascospores irregularly twisted, 2.0-2.5 $\mu \mathrm{m}$ broad; hyphophores present, umbelliform with pale stipe and dark brown, peltate and denticulate apex.

Remarks.-The nature of the hyphophores was not recognized in the original description, since Esslinger (1975) considered them to be postmature apothecia. Vězda and Poelt (1987) eventually established the connection between the hyphophores of Gomphillus americanus and those found in many taxa of Asterothyriaceae, and emended the family Gomphillaceae to include all genera with hyphophores.

Distribution.- Reported from North America (SE United States; Buck 1998; Esslinger 1975;
Ladd et al. 1994) and newly found in northern Argentina. The hyphophores of the Argentinian collections are slightly more robust that those in the specimen from the U.S.A. examined by us.

Specimens examined.-U.S.A. ОкLAнома: Cherokee County, J. T. Nickel Family Nature and Wildlife Preserve (J5 Ranch), $7 \mathrm{mi}$. NE of Tahlequah, Tully Hollow, $35^{\circ} 59^{\prime} 30^{\prime \prime} \mathrm{N}, 94^{\circ} 51^{\prime} 45^{\prime \prime} \mathrm{W}$, low sandstone bluffs along stream, in upland Quercus-dominated woods, 30 Oct 2000, Buck 38443 (CTES). ARGENTINA. Misiones: Guaraní, Predio Guaraní, 26 $54^{\prime}-59^{\prime}$ S, 54¹2-18' W, 9 Sep 1994, over Papillaria nigrescens, 9 Sep 1994, Schinini et al. 28811 (CTES); SALTA: Orán, Finca San Andrés, in Yungas, secondary forest, $28^{\circ} 04^{\prime} 23^{\prime \prime} \mathrm{S}, 64^{\circ} 45^{\prime} 07^{\prime \prime} \mathrm{W}$, over Schlotheimia aff. rugifolia, 28 Oct 1997, Schinini 34157 a (CTES).

Gomphillus Calycioides (Del. ex Duby) Nyl., Bot. Notiser 1853: 165. 1853, Mém. Soc. Sci. Nat. Cherbourg 2: 15. 1854; Baeomyces calycioides Del. ex Duby, Bot. Gall. 2: 636. 1830; Mycetodium calycioides (Del. ex Duby) A. Massal., Flora 39: 285. 1856, Sched. Crit. 3: 63. 1856; Gomphillus calycioides var. polycephalus Nyl., Syn. Meth. Lich. 1(2): 175. 1860, nom. illeg. Type. France, Despréaux s.n. (holotype: G!; isotype: HNYL!).

Baeomyces microcephalus Taylor in Mackay, Fl. Hibern 2: 78. 1836; Gomphillus calycioides var. microcephalus (Taylor) Nyl., Syn. Meth. Lich. 1(2): 175. 1860; Gomphillus calycioides f. microcephalus (Taylor) Crombie, Monogr. Lich. 1: 108. 1894. Type. Ireland, Taylor s.n. (holotype: $\mathrm{FH}$; isotype: H-NYL!).

Diagnostic characters.-Apothecia vertically elongate, dark brown; ascospores straight or irregularly twisted, 2.0-4.0 $\mu \mathrm{m}$ broad; hyphophores absent.

Remarks.-We studied material collected by Imshaug in the West Indies and South America. All specimens from the West Indies belong to Gomphillus ophiosporus, whereas the material from Chile is typical $G$. calycioides, except one specimen whose apothecia have a strongly irregular surface that resembles the apothecium of a Morchella species (see Sérusiaux \& Lücking 2005)

Distribution.-Possibly widespread in temperate regions but not yet known from tropical areas. $\mathrm{Re}$ ported from North America (SE United States), South America (Chile), oceanic parts of western Europe (Purvis et al. 1992; Tavares 1946; Tønsberg \& Øvstedal 1982), Macaronesia, and Hawaii.

Specimens examined.-FRANCE. Pyrénées Atlantiques, crevasses d Holcarté (S de Tardets-Sorholus), 400 m, Aug 1985, Sérusiaux 7607, 7609 (LG). PORTUGAL. Lisboa: Estremadura, Serra de Sintra, Parque da Pena, vicinity of Cruz Alta, May 1964, Imshaug 36256 (MSC). CHILE. X Región (Los Lagos): Osorno, along road at Refugio Antillanca, Sep 1969, Imshaug \& Ohlsson 42888 (MSc); Juán Fernández Islands: Más a Tierra [= Robinson Crusoe Is.], El Yunque, Dec 1965, Imshaug 37779 (MSC).

GoMPHILlus MORCHELloIDES Lücking \& Sérus., THE 
Bryologist 108: 487 (2005). Type. Papua New Guinea, Lambley 40/86 (holotype: BM!).

Diagnostic characters.-Apothecia vertically elongate and shortly stipitate at base, dark brown to brownish black, cerebriform with irregular foveolate surface; ascospores slightly and irregularly twisted, 2.0-3.0 $\mu \mathrm{m}$ broad; hyphophores absent.

Remarks. - This species was first reported as Gomphillus ophiosporus from Papua New Guinea (Aptroot et al. 1997) and as G. calycioides from Chile (Buck 1998), the latter based on collections made by Henry Imshaug. Restudy of these collections by the second author revealed that it deals with an undescribed species, differing from other species of the genus by its cerebriform, shortly stalked apothecia. The ascospores are most similar to those of $G$. calycioides (Lücking \& Sérusiaux 2005).

Distribution.-Thus far Southern Hemispheric, in Chile and the upper montane zone in Papua New Guinea (Lücking \& Sérusiaux 2005).

Specimen examined.-CHILE. X Región (Los Lagos): Chiloé, Patagonian Channels, along shore of harbor, Pto Ballena, Sep 1969, Imshaug \& Ohlsson 43151 (MSC).

GOMPHILLUS OPHIOSPORUS Kalb \& Vězda, Biblioth. Lichenol. 29: 30 (1988). Type. Ecuador, Kalb s.n. (holotype: hb. Kalb!; isotypes: GZU!, UPS!, hb. Vězda!).

Diagnostic characters.-Apothecia vertically elongate, dark brown; ascospores spirally twisted, 1.5-2.0 $\mathrm{mm}$ broad; hyphophores absent.

Remarks.-Gomphillus ophiosporus seems to be the only genuinely tropical species of the genus. It it rather widespread and common throughout the Neotropics, although certainly undercollected (the report from Papua New Guinea by Aptroot et al., 1997, is G. morchelloides). Among the five species known so far, $G$. ophiosporus is easily recognized by its very thin ascospores which are strongly spirally twisted within the asci.

Distribution.-Neotropics. Reported from Costa Rica, Ecuador, and Brazil (Buck 1998; Kalb \& Vězda 1988).

Specimens examined.-HAITI. Sud: Massif de la Hotte, along W ridge leading to Pic Macaya, Morne Macaya, Jul 1958, Wetmore \& Imshaug 3246 (MSC); ibid., Morne Macaya, Jul 1958, Wetmore \& Imshaug 3246, 3299 (MSC); ibid, near summit of Morne Macaya, Wetmore \& Imshaug 3332 (MSC). DOMINICAN REPUBLIC. Cordillera Central, Armando Bermudez National Park, on slope of Pico del Yaque, above Río Yaque del Norte valley, Aug 1958, Imshaug \& Wetmore 23633 (MSC). JAMAICA. St. Thomas Parish: Blue Mountains, trail to Main Ridge Gap from Monkey Hill, Feb 1953, Imshaug 14606 (MSC); New Haven Gap, Mar 1953, Imshaug 15131 (MSC). LESSER ANTILlES. Guadeloupe: Basse-Terre, La Soufrière, laudes et fourrés sur laves récentes et perturbées, 1,450 m, 27 Apr 1995, Sérusiaux s.n. (LG).

\section{ACKNOWLEDGMENTS}

LIF is indepted to the Myndel Botanical Foundation, for supporting the collecting trip during which the new species, Gomphillus pedersenii, was collected. The visit of RL to Michigan State University to study the collections of Henry Imshaug was supported by an NSF grant to Alan Prather and Alan Fryday at Michigan State University (DBI 0237401). The collections of Gomphillus ophiosporus from Costa Rica were gathered in the framework of the TICOLICHEN project, supported by an NSF grant to The Field Museum (PI Robert Lücking; DEB 0206125).

\section{LiTERATURE Cited}

Aptroot, A., P. Diederich, E. Sérusiaux \& H. J. M. SipMAN. 1997. Lichens and lichenicolous fungi from New Guinea. Bibliotheca Lichenologica 64: 1-220.

BuCK, W. R. 1998. Lichen flora of eastern North America: the genus Gomphillus (Gomphillaceae), pp. 71-76. In M. G. Glenn, R. C. Harris, R. Dirig \& M. S. Cole (eds.), Lichenographia Thomsoniana: North American Lichenology in Honor of John W. Thomson. Mycotaxon Ltd., Ithaca, NY.

Dennetière, B. \& J. Péroni. 1998. Approche phylogénétique des Gomphillaceae. Cryptogamie, Bryologie Lichénologie 19: 105-121.

Duvigneaud, P. 1944. Remarques sur la systématique des lichens à podétions. Bulletin du Jardin Botanique de l'État (Bruxelles) 17: 149-155.

EssLinger, T. L. 1975. A new North American species of the lichen genus Gomphillus. Mycotaxon 1: 189-192.

Ferraro, L. I. 2000. Novedades en los géneros Calenia y Tricharia (Gomphillaceae, ascomycetes foliícolas liquenizados) de Argentina y Paraguay oriental. Bonplandia 10: 129-137.

- 2004. Morphological diversity in the hyphophores of Gomphillaceae (Ostropales, lichenized Ascomycetes). Fungal Diversity 15: 153-169.

\& R. LÜCKING. 2003. Gyalectidium aurelii (Ostropales: Gomphillaceae), a new foliicolous lichen from the state of Mato Grosso, Brazil. Acta Botanica Brasilica 17: 619-622.

— \& E. SÉrusiaux. 2001. A world monograph of the lichen genus Gyalectidium (Gomphillaceae). Botanical Journal of the Linnean Society 137: 311-345.

- \& A. VĚZDA. 1989. Tricharia cuneata Ferraro \& Vězda sp. nov., liquen folicola del NE de Argentina. Bonplandia 6: 111-115.

HafellneR, J. 1984. Studien in Richtung einer natürlicheren Gliederung der Sammelfamilien Lecanoraceae und Lecideaceae. Beiheft zur Nova Hedwigia 79: 241-371.

- 1988. Principles of classification and main taxonomic groups, pp. 41-52. In M. Galun (ed.), CRC Handbook of Lichenology, Vol. III. CRC Press, Boca Raton, FL.

Kalb, K., R. Lücking \& E. Sérusiaux. 2000. Studies in Bacidia sensu lato (lichenized Ascomycetes: Lecanorales). I. The genus Bapalmuia. Mycotaxon 75: 281309.

— \& A. VĚZDA. 1988. Neue oder bemerkenswerte Arten der Flechtenfamilie Gomphillaceae in der Neotropis. Bibliotheca Lichenologica 29: 1-80.

LadD, D., G. Wilhelm \& R. C. Harris. 1994. Additions to the lichen flora of Missouri. Evansia 11: 131-138.

LÜCKING, R. 1997. Additions and corrections to the knowledge of the foliicolous lichen flora of Costa 
Rica. The family Gomphillaceae. Bibliotheca Lichenologica 65: 1-109.

W. R. Buck, E. Sérusiaux \& L. I. Ferraro. 2005 . Gomphillus caribaeus belongs in the new genus Bryogomphus (Lecanorales: Pilocarpaceae). THE BRYOLOGIST 108: 481-486.

\& SÉRUSIAUX, E. 2005. Gomphillus morchelloides (Ostropales: Gomphillaceae), a new lichen species from Chile and Papua New Guinea. ThE BRYOLOGIST 108: 487-490.

\& A. VĚzDA. 2005a. Phylogeny and systematics of the lichen family Gomphillaceae (Ostropales) inferred from cladistic analysis of phenotype data. Lichenologist 37: 123-170.

B. L. Stuart \& H. T. Lumbsch. 2004. Phylogenetic relationships of Gomphillaceae and Asterothyriaceae: evidence from a combined Bayesian analysis of nuclear and mitochondrial sequences. Mycologia 96: 283-294.

Purvis, O. W., B. J. Coppins, D. L. Hawksworth, P. W. JAMES \& D. M. MOORE (EDS.) 1992. The Lichen Flora of Great Britain and Ireland. Natural History Museum Publications \& British Lichen Society, London. 710 pp.
RÄSÄNEN, V. 1943. Das System der Flechten. Übersicht mit Bestimmungstabellen der natürlichen Flechtenfamilien, ihrer Gattungen, Untergattungen, Sektionen und Untersektionen. Acta Botanica Fennica 33: 1-82.

SANTESSON, R. 1952. Foliicolous lichens I. A revision of the taxonomy of the obligately foliicolous, lichenized fungi. Symbolae Botanicae Upsalienses 12 (1): 1-590.

TAVARES, C. N. 1946. Notes lichenologiques V. Portugaliae Acta Biologica, Séries B, 2: 161-176.

TønsberG, T. \& D. O. Øvstedal. 1982. Noen interessante lavfunn. III. Blyttia 40: 59-63.

VĚZDA, A. \& J. PoElT. 1987. Flechtensystematische Studien XII. Die Familie Gomphillaceae und ihre Gliederung. Folia Geobotanica et Phytotaxonomica 22: 179-198.

Watson, W. 1929. The classification of lichens I/II. New Phytologist 28: 1-36,-85-116.

Zahlbruckner, A. 1926. Flechten. Spezieller Teil. In A. Engler \& K. Prantl (eds.), Die natürlichen Pflanzenfamilien 8(1). Engelmann, Leipzig.

ms. received May 26, 2005; accepted July 28, 2005. 


\section{Table of Contents 108(4)}

Robert Lücking, William R. Buck, Emmanuël Sérusiaux, and Lidia I. Ferraro Gomphillus caribaeus Belongs in the New Genus Bryogomphus

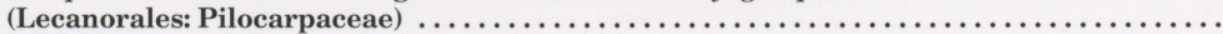

RoBERT LÜCKING AND EMmANUËL SÉRUSIAUX

Gomphillus morchelloides (Ostropales: Gomphillaceae), A New Lichen

Species from Chile and Papua New Guinea $\ldots \ldots \ldots \ldots \ldots \ldots \ldots \ldots \ldots \ldots \ldots$

Lidia I. FERraro AND RoBERT LÜCKING

The Genus Gomphillus (Ostropales: Gomphillaceae) in the Americas, With the New

Species Gomphillus pedersenii from Argentina $\ldots \ldots \ldots \ldots \ldots \ldots \ldots \ldots \ldots \ldots \ldots$

Sharon Bartholomew-Began and Nicole L. Jones

Juvenile Gametophyte Development in the Blasiales (Marchantiophyta; Metzgeriidae).

1. Receptacular Gemma/Gemmaling Ontogeny of Blasia pusilla $\ldots \ldots \ldots \ldots \ldots \ldots \ldots$

Marlene LidÉn AND Olga Hilmo

Population Characteristics of the Suboceanic Lichen Platismatia norvegica in Core

and Fringe Habitats: Relations to Macroclimate, Substrate, and Proximity to Streams .. 506

JoHn ATwoon

The Distribution of Buxbaumia minakatae in Pennsylvania and the Lectotypification

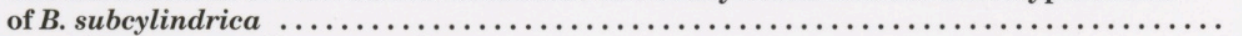

MatThias Schultz AND BURKHARD BÜDEL

Phloeopeccania anemoides, a New Lichen Species from Baja California Sur and

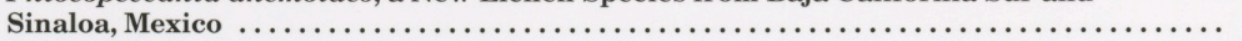

Jan-Peter Frahm and Angela E. Newton

A New Contribution to the Moss Flora of Dominican Amber

THMAR BREUSS

A New Species of the Lichen Genus Neocatapyrenium (Verrucariaceae) from

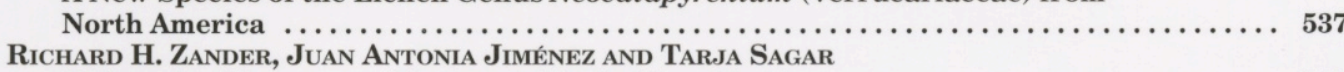

Didymodon bistratosus (Pottiaceae) in the New World $\ldots \ldots \ldots \ldots \ldots \ldots \ldots \ldots \ldots \ldots \ldots \ldots 540$

James P. Bennett and Clifford M. Wetmore

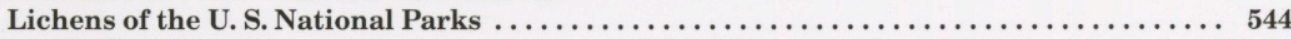

Natalie L. Cleavitt

Patterns, Hypotheses and Processes in the Biology of Rare Bryophytes . . . . . . . 554

Matthias Schultz

An Overview of Lichinella in the Southwestern United States and Northwestern

Mexico, and the New Species Lichinella granulosa $\ldots \ldots \ldots \ldots \ldots \ldots \ldots \ldots \ldots \ldots$

YANG LiU, Yu JiA, Wei Wang, Zhi-Duan Chen AND Yin-Long QIU

A Taxonomic Reassessment of Microdendron (Polytrichaceae) Inferred from Molecular

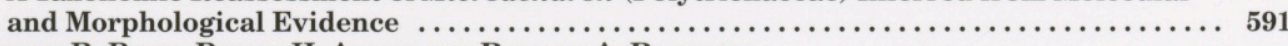

William R. Buck, Bruce H. Allen and Ronald A. Pursell

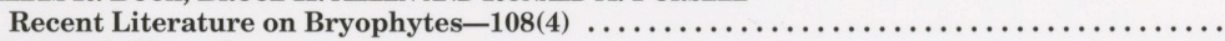

THEODORE L. Esslinger

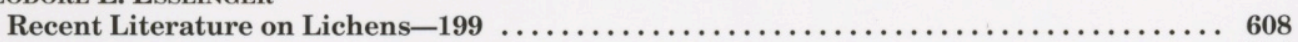

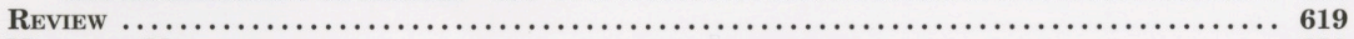

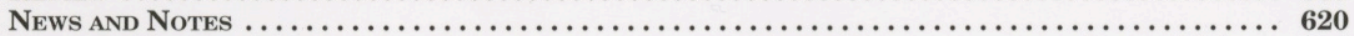

Index to Volume $108 \ldots \ldots \ldots \ldots \ldots \ldots \ldots \ldots \ldots$ EmLy Poworoznek AND David M. LANE 621

Cover Illustration: Apothecia of Bryogomphus gen. nov. and a hyphophore of Gomphillus pedersenii sp. nov.; the background is the cloud-covered vegetation of Volcán Tenorio National Park in Costa Rica, that shelters an extraordinarily high diversity of bryophilous lichens. Photos taken by R. Lücking; see Lücking et al. triology of articles in this issue.

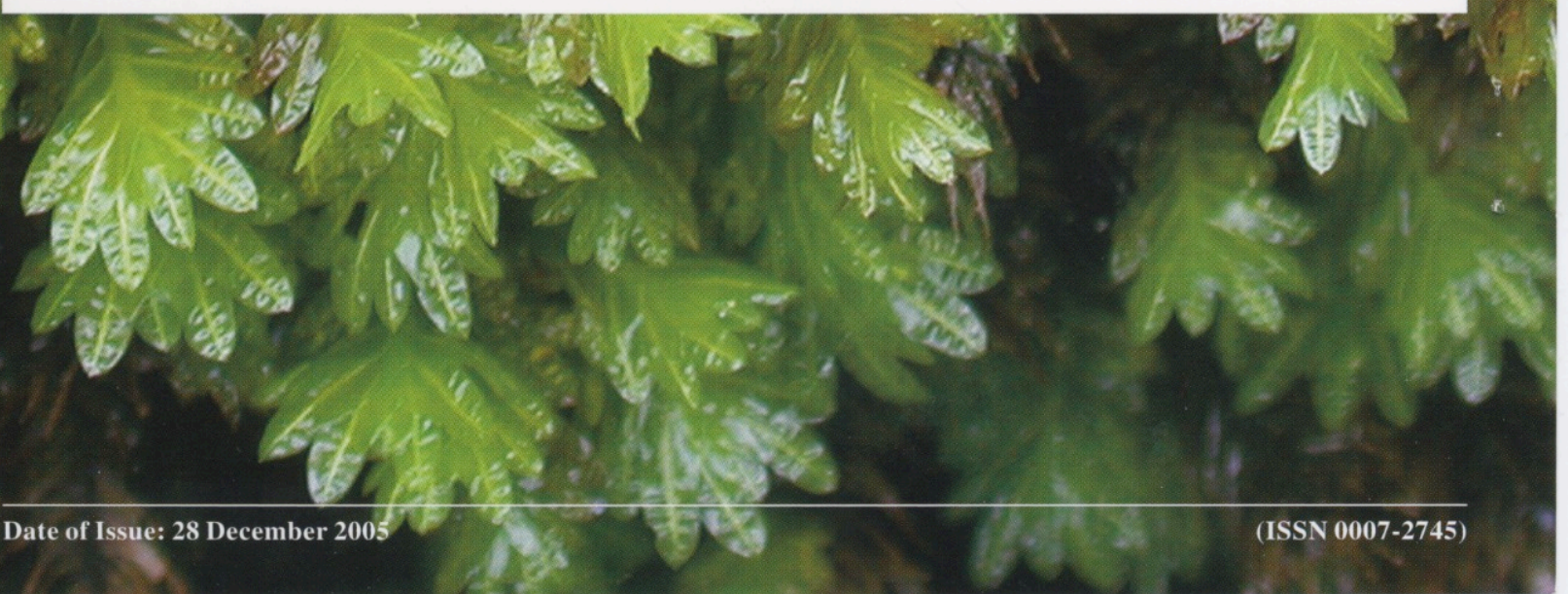

